\title{
Maritime Boundary Disputes between Indonesia and Malaysia in the Area of Ambalat Block: Some Optional Scenarios for Peaceful Settlement
}

\author{
Ida B. R. Supancana*
}

Maritime boundary issues have become a constraint in the relations between Indonesia and its neighboring countries, including Malaysia. One of the pending issues regarding the overlapping maritime boundary which is not yet to be resolved is the Ambalat area. The primary purpose of this research is to suggest possible senarioa to resolve the maritime delimitation dispute between Indonesia and Malaysia around Ambalt peacefully under international law. This article is prepared to explore all available ways for the peaceful settlement on Ambalat issue.The author will examine the diplomatic channel, ASEAN Way dispute settlement mechanism, adjudication process (litigation and arbitration), and dispute settlement under the UN Convention on the Law of the Sea. He will also epropose other innovative approach, such like Joint Development Zone. The result of such examination can be used as considerations for the way forward.

\section{Keywords}

Ambalat, Peaceful Settlement, Maritime Boundary Disputes, Indonesia, Malaysia, ASEAN Way, JDZ

\footnotetext{
* Professor of International Law at Atma Jaya University School of Law, Jakarta, Indonesia. LL.B. (Univ. of Padjajaran), LL.M. (Indonesia). Ph.D. (Leiden). ORCID: http://orcid.org/0000-0002-9810-4865. The author would like to thank Maman Usman Rasidi (Center for Regulatory Research), Yoshua Saroinsong (Attorney at Law at MKK Law Firm), Ida Ayu Tita Rahmawidiani (Padjajaran School of Law) for their kind and substantive assistance in conducting researches on this subject, namely. He may be contacted at: supancana@yahoo.com / Address: Faculty of Law, Atmajaya Catholic University, 1. Jenderal Sudirman 51, Jakarta, 12930 Indonesia. DOI: http://dx.doi.org/10.14330/jeail.2015.8.1.09
} 


\section{Background}

The Ambalat Area is expected to have rich with oil and gas reserves totaling to a value of USD 65 billion. The area allegedly contains vast resources ranging from 100 millions to a billion barrels of oil. ${ }^{1}$ The working area of oil and and gas mining exploration in the Northern Part of East Kalimantan (Borneo) has been managed by Indonesia since 1967. The Government of Indonesia has granted contracts to some international oil companies such as: (1) Total Indonesie at Bunyu Island (1967); (2) British Petroleum at the off-shore of East Kalimantan (1970); (3)Hadson Bunyu for Bunyu Block (1983); (4) ENI Bukat for Bukat Block (1988); and (5) ENI Ambalat for Ambalat Block (1999). ${ }^{2}$

There had been no protests or complaints by the Government of Malaysia concerning the above contracts until December 30, 2004 when Indonesia signed the contract with Unocal for East Ambalat. The Government of Malaysia finally sent the protest in the form of three (3) diplomatic notes. ${ }^{3}$

On February 16, 2005, Petronas (A Malaysian State Oil Company) approved a Production Sharing Contract to Shell (Royal Dutch Oil Company) for two blocks, namely Blocks ND 6 and ND 7 which overlap with Ambalat and East Ambalat Blocks of Indonesia. Actually in 2003 Malaysia has conducted seismic test in the said area called $\mathrm{X}, \mathrm{Y}$ and $\mathrm{Z}$ zones. ${ }^{4}$

The Government of Indonesia protested the Production Sharing Contract between Malaysia and Shell as it was deemed violate the sovereignty of Indonesia. ${ }^{5}$ In 2005 there were several incidents between the two countries which involved civilian ships as well as military warships. It was quite sensitive because both military arms (Indonesia and Malaysia) have taken their position ready for military action (i.e. Karang Unarang Lighthouse building). ${ }^{6}$ Figure 1 shows the Area and the

1 For details, see G. Triggs, Maritime Boundary Disputes in South China Sea: International Legal Issues, at 3, Legal Studies Research Paper no 09/37, Sydney Law School (May 2009). See also, ENI finds oil in area claimed by Indonesia, Malaysia, JAKARTA Post, Mar. 18, 2005.

2 For details on the background of Ambalat Case, see I. Supancana, Prospects for Settlement of Disputes of Ambalat Case from the Perspective of International Law [Prospek Penyelesaian Sengketa Ambalat dalam Perspektif Hukum Internasional], Paper presented at Seminar on Ambalat at Ngurah Rai University, Denpasar-Bali, April 30, 2005.

$3 \quad$ Id.

4 For further information see I Made Andi Arsana, Ambalat, What's Up?, available at https://geoboundaries. wordpress.com/2005/03/08/Ambalat-whats-up (last visited on Feb. 2, 2015).

5 Makmur Keliat, Shelving the Issue of Sovereignty in the Ambalat Dispute, JAKARTA Post, (Mar. 15, 2005).

6 Djoko Harmantyo, Ambalat Issues: a Preliminary Study on the Problem of Indonesian Territorial Boundaries, 38 INDONESIAN J. GEO. (2006). 
overlapping claims of Ambalat.

Figure 1: The Disputes Territorial Boundary around Ambalat Areas ${ }^{7}$

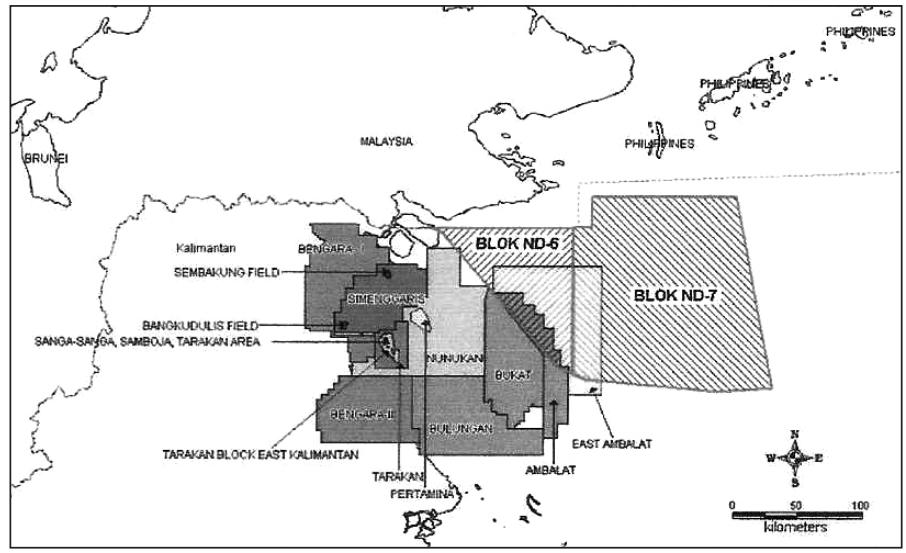

The primary purpose of this research is to suggest possible senarios in resolving the maritime delimitation dispute between Indonesia and Malaysia around Ambalt peacefully under international law. This paper is composed of four parts including short Introduction and Conclusion. Part two will discuss the basic position of Indonesia and Malaysia. Part three will suggest some options for peaceful settlement of Ambalat dispute. Part four will show the way forward.

\section{The Basic Position of Indonesia and Malaysia}

\section{A. The Basic Position of Indonesia}

Indonesia is of the opinion that Malaysian claims over Ambalat are not valid/ legitimate due to the alleged inconsistency with the existing rules of international law of the sea. The Malaysian method of determining maritime delimitation by using straight base lines from point to point is not in accordance with Article 7 of the United Nations Convention on the Law of the Sea of 1982 ("UNCLOS"), which

7 Bakosurtanal (Indonesian Coordinating Agency for National Survey and Mapping) 2004.

8 United Nations Convention on the Law of the Sea, signed on Dec. 10, 1982, 1833 U.N.T.S 3 [1994] I.L.M. 1261 (1982) [hereinafter UNCLOS]. For details on the content of UNCLOS III, see R. Churchill \& A. Lowe, The LAW 
requires: (1) Coast line that indented and cut into; ${ }^{9}$ (2) There is a fringe of island along the cost; ${ }^{10}$ (3) The existence of unstable coast, ${ }^{11}$ (4) Straight base lines may not depart appreciably from the general direction of the coast; ${ }^{12}$ and (5) Prohibit straight base line which cut into territorial waters of a country/state from exclusive economic zone or high seas/open seas. All the above requirements, however, are not met by Malaysia. $^{13}$

The use of straight base line from point to point from the outer point of Sipadan and Ligitan are not in line with the decision of the International Court of Justice ("ICJ") In Pulau Sipadan and Pulau Ligitan case, Judge Shigeru Oda states:

...the present judgement determining sovereignty over the island does not necessarily have a direct bearing on the delimitation of the continental shelf, which has been a subject of disputes between the two States since the late 1960's. ${ }^{14}$

In this case, the Court further adjudicated:

The Court can not take into consideration acts having taken place after the date in which the dispute between the parties crystallized unless such acts are not undertaken for the purpose of improving the legal position of the parties which relies on them. ${ }^{15}$

The above formulation has clearly shown that the use of Malaysian Map (Charts) of 1979, applied unilaterally by Malaysia is neither valid nor legitimate. A State cannot bind another State with its own map unless the latter State agrees. It would be possibly argued that a State could acquiesce to a particular situation over time, but it is not the case here. This implies that the 1979 Chart must be acceptable only when Malaysia used in a scientific and legal manner. If the 1979 Chart fulfils only partial needs and interests, it can not be used in such a way disregarding State's

of the Sea (1983). See also Yoshifumi Tanaka, The International Law of the Sea (2012).

UNCLOS art. 7 (1).

Id.

Id. art. 7 (2).

Id. art. 7 (3).

3 Bantarto Bandoro, Ambalat, Where the Game Natios Play, Jakarta Post, Mar. 16, 2005.

14 See Sovereignty over Pulau Ligitan and Pulau Sipadan (Indon. v. Malay.), Judgement, 2002, I.C.J. (Dec. 17) [hereinafter Sovereignty over Pulau Ligitan and Pulau Sipadan], available at http://www.icj-cij.org/docket/index.php ?p1=3\&p2=3\&code=inma\&case=102\&k=df See also S. BREAU, Question AND ANSWERs: InTERNATIONAL LAW 88-167 (2013); Hasjim Djalal, Dispute between Indonesia and Malaysia on the Sovereignty over Sipadan and Ligitan Islands, 12 OpINIO JuRIS (2013).

15 Id. See Sovereignty over Pulau Ligitan and Pulau Sipadan, \ 135. 
sovereignty. ${ }^{16}$

Concerning the five base points (Sebatik, Karang Benda, Karang Unarang, Bunyu Island, and Maratua Island) and the straight base line adopted by Indonesia, Indonesia argues that they are in accordance with the Archipelagic State Principles. ${ }^{17}$

The Use of Karang Unarang Island as base point, for instance, is justified, considering that it is located nine (9) nautical miles from island of Sebatik, 6.7 nautical miles from the territory of Indonesia.

Indonesia's claim is also supported by historical facts in that Ambalat was previosly a part of Bulungan Sultanate, which has been an integral land of Indonesia since Indonesian Indpendence. This opinion is known as the chain of title argument. ${ }^{18}$ Actually, the disputed area has since 1967 been uninteruptedly operated by Indonesia without any protest from Malaysia. The lack of protests can be interpreted as a kind of implied recognition.

\section{B. The Basic Position of Malaysia}

Malaysia is of the opinion that the (oil and gas) disputed area granted to Shell based on Production Sharing Contract on the February 19, 2005 as referred to by Malaysia as $\mathrm{X}, \mathrm{Y}$ and $\mathrm{Z}$ zones, is within the territoral sovereignty of Malaysia. ${ }^{19}$ Malaysia argued that The base points and straight base lines has been drawn from Sebatik, Batuan Tangan, Pulau Sipadan and Pulau Ligitan, following Article 7, para 1 and para 3; which lays down that the requirements on fringing reef and islands do not depart appreciably from the gerneral direction of the coast.

Malaysia also asked Indonesia the legal basis of determining base points and base lines conducted by Indonesia. ${ }^{20}$ Malaysia questioned the building of the lighthouse by Indonesia in the island of Karang Unarang. ${ }^{21}$

16 This assessment was made by Clive Schofield, a former director of the International Boundary Research Unit ("IBRU") as quoted by Arsana, supra note 4.

17 UNCLOS art. 47 1. It reads: "An archipelagic State may draw straight archipelagic baselines joining the outermost points of the outermost islands and drying reefs of the archipelago .........etc." For details on Archipelagic principles, see Churchill \& Lowe, supra note 8, at 90-100.

18 Supra note 4.

19 Supra note 13.

20 Arif Havas Oegroseno, Determination of Maritime Boundary at Sulawesi Sea [Penetapan Batas Maritim Laut Sulawesi], in Sutisna Sabar (ed), The Perspective of Territorial Boundary: the Problems of Indonesian Maritime Boundary [Pandang Wilayah Perbatasan; Aspek Permasalahan Batas Maritim Indonesia] (2006).

21 Id. See also C. Schofield \& IMA Arsana, Ambalat Revised: The Way Forward, Jakarta Post, June 5, 2005, available at $\mathrm{https://geoboundaries.wordpress.com/2005/06/10/the-jakarta-posts-ambalat-revised-the-way-forward}$ (last visited on May 7, 2015). 


\section{Some Options for Peaceful Settlement}

\section{A. General}

By the end of 2015, the ASEAN will become the ASEAN Community with its three pillars, namely: the ASEAN Security Community (“ASC"), the ASEAN Economic Community ("AEC") and the ASEAN Social and Cultural Community ("ASCC"). It is imperative for the ASEAN members to settle their disputes peacefully. The use of force as a way to settle the disputes both unilaterally and mutilaterally ${ }^{23}$ should be prohibited. Instead, all efforts must be directed towards exploring all available peaceful means. ${ }^{24}$

For the peaceful settlement of Ambalat dispute, some available options are open to be explored through diplomatic channel ASEAN regional framework (hereinafter ASEAN Way); and adjudication process.

\section{B. Settlement of Disputes through Diplomatic Channel}

A negotiation process is the principal means of handling all disputes. ${ }^{25}$ Negotiation is implied more frequently than all other methods put together. ${ }^{26}$ In general, settlement of disputes through negotiation can be divided into direct and indirect one in which a third party is involved.

The first phase of diplomatic negotiation between Indonesia and Malaysia concerning the Ambalat case was conducted on March 22-23, 2005. On the first meeting the two parties have submitted their position and its legal basis. ${ }^{27}$ The second meeting held in Malaysia in May 2005 was aimed at exploring how the overlapping claims of Ambalat can be settled by the two parties. Although there was no dead-lock in the negotiation process, no comprehensive and mutually acceptable solution have been agreed by the two parties, either.

In the January 2006 meeting, while admitting that there had been no breakthrough

22 For details, see I. Supancana, The Roadmap toward the Creation of ASEAN Security in 2015: Legal Perspectives, $1 \mathrm{~J}$. EAST Asia \& InT'L L. 333 (2008).

23 Breau, supra note 14 , at 172-201.

24 U.N. Charter arts. 2(3) \& 33. For details, see J. Merrils, International Dispute Settlement 2 (2012).

25 Merrils, id.

26 Id.

27 Report of the Indonesian Delegates on the Negotiation between Indonesia and Malaysia concerning Ambalat (The Report is not open to the public because it is a secret government document from the Indoensian Ministry of Foreign Affairs). 
in the negotiation process, the two heads of State for the first time publicly discussed the possibility of joint development in disputed maritime zones. ${ }^{28}$ In March 2008, the Indonesian President called on the Ambalat Block negotiating teams to work more effective and bring the matters to a conclusion. ${ }^{29}$

In addition to negotiation, some more mechanisms may be also applied such as consultation, mediation, concilation, inquiry, etc. Consultation can be invoked when a government anticipates that a decision or a proposed course of action may harm another State; discussions with the affected party can provide a way of heading off a dispute by creating an opportunity for adjustment and accommodation. ${ }^{30}$ Consultation is particularly valuable when it supplies useful information at the most appropriate time. $^{31}$

In mediation, a third Party (or country) acting as mediator, would try to make each contesting party understand the other's point of view. A mediator will meet each party privately and listen to their respective view point, stress common interests, and try to help them reach a settlement. ${ }^{32}$

Meanwhile in conciliation, the conciliator listens to the two parties, hears their different position, and then sets forth a proposed settlement agreement, representing what the conciliator believes to be a fair compromise of the dispute. ${ }^{33}$

Another form of settlement involving a third party is by way of 'inquiry.' Here, an ad hoc commission of inquiry would provide the disputed parties with an objective assessment as the result of the inquiry. ${ }^{34}$ 'Inquiry' has been employed in cases in which 'honour' and 'essential interests' were unquestionably involved, for the determination of legal as well as factual issues. ${ }^{35}$

In the meantime, the third party which renders good offices has accomplished its mission as soon as it has brought the parties into contact and perhaps round the table. Unlike mediation it does not participate in the negotiations and makes no own proposal to solve the controversy. ${ }^{36}$

D. Weatherbee, International Relations In Southeast Asia: The Struggle for Autonomy 142 (2009).

29 D. Loh, Malaysia and Indonesia on Common Ground, New Straits Times, Mar. 9, 2008 , as quoted at D. Weatherbee, International Relations in Southeast Asia: The Struggle for Autonomy 142 (2009).

30 Id. at 2-3.

31 Id. at 3.

32 M. Moses, Principles And Practice Of International Commercial Arbitration 13-4 (2008).

33 Id. at 14.

34 Merrils, supra note 24 , at 41.

35 Id. at 54.

36 For details on good offices and other means for peaceful settlement of the disputes, see M. BEDJAOUI ED., International Law: Achievement And Prospects, Unesco-Paris Title Two 501-17 (1991). 


\section{ASEAN Way Dispute Settlement ${ }^{37}$}

The ASEAN way describes what is claimed to be South East Asia's distinctive approach to inter-State relations. It assumes the common interest in a peaceful, harmonious, and stable regional international order in which the ASEAN States interact with each other on the basis of their shared acceptance of common behavioral norms. ${ }^{38}$ The principle of concession-based decision making is one of the most important principles of the ASEAN Way. ${ }^{39}$

The ASEAN Way is in the center of the ASEAN security culture which consists of the following elements - sovereign equality; non-recourse to the use of force; non-interference and non-intervention; non-involvement of the ASEAN in bilateral conflict; quiet diplomacy; and mutual respect and tolerance. ${ }^{40}$ The application of the ASEAN way has two strategic goals. The first is not to allow bilateral disputes between ASEAN states disrupts wider regional stability and the functioning of ASEAN itself. The second is to not let bilateral issues between ASEAN states and non-member ASEAN states negatively affect intra -ASEAN relations. ${ }^{41}$ The following are the main instruments of dispute settlement under the ASEAN Framework:

\subsection{Treaty of Amity and Cooperation in Southeast Asia;}

The 1976 Treaty of Amity and Cooperation in Southeast Asia is a legally binding instrument to promote perpetual peace, everlasting amity and cooperation in the region.This Treaty has been accepted by a growing number of countries outside Southeast Asia. Numbers of countries like Japan, Pakistan, Republic of Korea, Papua New Guinea, China and India have acceded the Treaty. These accessions are a show of political support for ASEAN's principles of peaceful coexistence, friendly consultation and resolution of conflict, and goodwill cooperation. ${ }^{43}$ Under the TAC, dispute can be

37 For details on ASEAN Way, see F. Frost, ASEAN and Regional Cooperation: recent Development and Australia's Interests, Research Paper Australian Parliamentary Library 2013-2014, 5-8 (2013). See also W. Woon, Dispute Settlement the ASEAN Way (Oct. 17, 2011), available at http://cil.nus.edu.sg/wp/wp-content/uploads/2010/08/ DISPUTE-SETTLEMENT-IN-ASEAN-KSIL-ProfWalterWoon.pdf; D. Marshall, Dispute Settlement the ASEAN Way (Dec. 11, 2012), available at http://cil.nus.edu.sg/wp/wp-content/uploads/2010/01/WalterWoon-Dispute-Settlementthe-ASEAN-Way-2012.pdf (all last visited on May 2, 2015).

Supra note 28, at 128. See also Woon, id.

39 For details on the concession-based principle and its implementation, see supra note 22.

40 Supra note 37.

41 Supra note 28.

42 Adopted by the Head of State/Government at the First ASEAN Summit in Bali-Indonesia (Feb. 24, 1976), available at $\mathrm{http} / / / \mathrm{www}$.aseansec.org/1217.htm (last visited on May 2, 2015).

43 Supra note 22, at 327. The principles set forth in article 2 of the TAC in Southeast Asia consist of: mutual respect for independence, sovereignty, equality, territorial integrity, and national identity; the rigth of every state to lead its national 
settled by involving the ASEAN High Council. The High Council may offer its good offices or upon agreement of the disputed parties constitute itself into a Committee of Mediation, Enquiry or Conciliation. When deemed necessary, the High Council shall recommend appropriate measure for the prevention of deterioration of the dispute or the situation. ${ }^{44}$

\section{1996 Protocol on Dispute Settlement Mechanism; ${ }^{45}$}

This Protocol is based on article 9 of Framework Agreement in Enhancing ASEAN Economic Cooperation of 1992. This Protocol contains 12 articles and 2 appendixes. Appendix 1 dealing with Covered Agreements while appendix 2 on Working Procedures. The protocol cover settlement of (economic) disputes through consultation, good offices, conciliation, mediation, Senior Economic Official Meeting ("SEOM") which may establish a Panel to settle the disputes, and this protocol also contain provisions on responsibility of the secretariat.

\section{2004 ASEAN Protocol on Enhanced Dispute Settlement Mechanism; ${ }^{46}$}

This protocol replaces the 1996 Protocol on Dispute Settlement Mechanisms. It consists of 21 articles and 2 appendixes. Appendix 1 dealing with Covered Agreements and appendix 2 regulating Working Procedures of the Panel. Dispute settlement mechanism are enhanced to cover not only consultation, good offices, mediation, conciliation and panel, but also covers provisions on procedure for multiple complaints, third parties, appelate review, communication with the panel or appelate body, ASEAN dispute settlement mechanism fund, and venue for proceedings. Up to 2004 in the Covered Agreements there are about 46 international instruments covering: basic agreements, agreements, framework agreements, protocols and mutual recognition arrangements.

\section{2007 Charter of the Association of South East Asian Nations (Chapter VII) on Settlement of Disputes; ${ }^{47}$ \\ The Charter contains 55 articles and XIII chapters and 4 appendixes. Dispute}

existence free from external interference, subversion, or coercion; non interference to the internal affairs of one another; renunciation of the threat or use of force; and effective cooperation among themselves. For details, see supra note 28 , at 129-31.

44 Djalal, supra note 14, at 13.

45 Adopted by the Economic Ministers in Manila-Philipines on Nov. 20, 1996, available at http://www.aseansec.org/ 16654.htm (last visited on May 2, 2015).

46 Adopted by the Economic Ministers at the $10^{\text {th }}$ ASEAN Summit in Vientiane-Laos (Nov. 29, 2004), available at http://www.asean.org/16754.htm (last visited on May 2, 2015).

47 Adopted by the Heads of States/Government at the $13^{\text {th }}$ ASEAN Summit. For details, see W. Woon, The ASEAN Charter Dispute Settlement Mechanism, presented before the ALA $10^{\text {th }}$ General Assembly Meeting, available at http:// www.aseanlawassociation.org/speechespub-sing.html (last visited on May 7, 2015). 
settlement mechanism are stipulated in chapter VIII. Dispute settlement mechanism consists of general principles, good offices, conciliation, mediation, dispute settlement in specific instruments, establishment of dispute settlement mechanism, unresolved disputes, compliance, and UN Charter provisions and other relevant international procedures.

\section{2010 Protocol to the ASEAN Charter on Dispute Settlement Mechanism; ${ }^{48}$}

This protocol contains a very broad scope of dispute settlement mechanism covering: communication, consultation, good offices, mediation, concilitation, arbitration, third party, functions of the ASEAN Secretariat in the dispute settlement process. This protocol equipped with 4 annexes, namely: annex 1 on rules on Good Offices, annex 2 on rules of Mediation, annex 3 on rules of Conciliation and annex 4 on rules of Arbitration.

\section{Adjudication Process}

\section{Arbitration}

Arbitration is an adjudication process where the disputing parties agree to submit the case to an independent arbitration tribunal to examine and decide the case. The arbitrators are generally chosen by the conflicting parties. Parties also decide whether the arbitration will be administered by an international arbitration institution, or will be an ad hoc one. ${ }^{49}$

The Ambalat case can be settled through the Permanent Court of Arbitration ("PCA"). PCA is one of the oldest institutions dedicated to resolving international disputes with a variety of arbitration, conciliation and fact-finding services. It is primarily known for arbitrating disputes between States and State entities, including disputes arising out of various treaties. ${ }^{50}$ The PCA adopted two new sets of rules of arbitration in 1992-1993. The first set, from October 1992 is designed for optional use in resolving disputes between States, while the second set, from July 1993, is designed for disputes between States and non-States parties. Both sets are patterned after the United Nations Conference on International Trade Law ("UNCITRAL") Rules of Arbitration. ${ }^{51}$

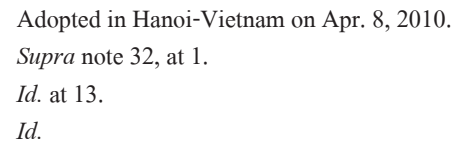




\section{Litigation through the International Court of Justice}

A second possibility to settle the Ambalat disputes by way of the International Court of Justice ("ICJ"). There were some ICJ cases related to the maritime affairs involving the ASEAN such as Sovereignty over Pedra Branca/Pulau Batu Puteh Middle Rocks and South Ledge (Malaysia vs Singapore) ${ }^{52}$ and Sovereignty over Pulau Ligitan and Pulau Sipadan (Indonesia vs. Malaysia). ${ }^{53}$ In the Sovereighty over Pulau Ligitan and Pulau Sipadan case, Hasjim Djalal maintains that, to settle territorial sovereignty issues as well as maritime boundary delimitations of course would bring a lot of risk because the solution would generally be "winning or losing." ${ }^{54}$ He has further stated that it was really dramatic for Indonesia to agree to go to the Court for the first time on a purely legal matters, and to accept the decisions of the Court as final and binding, without seriously attempting other mechanism allowed by the UN Charter. ${ }^{55}$ After Indonesia was defeated in Pulau Sipadan and Pulau Ligitan case, it seems that the Government of Indonesia is reluctant to bring the case of Ambalat to the ICJ.

\section{E. Settlement of Disputes under ths UN Convention on the Law of the Sea}

The UNCLOS lays down a basic scheme for the settlement of disputes arising from the interpretation and application of the Convention and makes exception from this for certain categories of dispute. The exceptions are largely motivated by the fact that States are particularly unwilling to allow some kind of disputes, which involve their vital interests more than others, to be determined by third party procedures, and to a lesser extent by the need to provide specialist panels to adjudicate on some questions. $^{56}$

The procedures for the settlement of disputes are as follows: States must settle disputes by peaceful means ${ }^{57}$ and are always free to agree to adopt some means other than that prescribed in the UNCLOS. ${ }^{58}$ If the parties to a dispute fail to reach a

\footnotetext{
52 Sovereignty over Pedra Branca/Pulau Batu Puteh Middle Rocks and South Ledge (Malay. v Sing.), Judgment, 2008, I.C.J. (May 23), available at http://www.icj-cij.org/docket/index.php?p1=3\&p2=3\&k=2b\&case=130 (last visited on May 8, 2015).

53 Sovereignty over Pulau Ligitan and Pulau Sipadan.

54 Djalal, supra note 14 , at 25.

55 Id.

56 Churchill \& Lowe, supra note 8, at 295.

57 UNCLOS art. 279.

58 Id. art. 280.
} 
settlement through agreed procedures, one of them may invite the other to submit to the conciliation procedures. ${ }^{59}$ If this invitation is accepted, each party chooses two conciliators from a list one of whom may be one of its nationals. Both State are entitled to nominate four people. Those four conciliators then select a fifth, who acts as chairman. The panel has to hear the parties' arguments, report them, and make any recommendations within one year. If the report is accepted and implemented, all is well. If not, however, the conciliation procedure is deemed to be terminated. ${ }^{60}$ Following the mechanism of mandatory dispute resolution, ${ }^{61}$ any dispute not resolved under Articles 279, 280, 282 and 284 of the UNCLOS is to be referred for compulsory settlement. ${ }^{62}$ States may, on signing the Convention or at some later date, choose one or more of the following forum to decide ${ }^{63}$ :

1. The International Tribunal for the Law of the Sea;

2. The International Court of Justice;

3. An Arbitral Tribunal constituted under Annex VII of the UNCLOS; or for specified kind of disputes; or

4. A Special Arbitral Tribunal under Annex VIII. ${ }^{64}$

The UNCLOS set up the International Tribunal on the Law of the Sea ("ITLOS") under Annex VI of the UNCLOS.$^{65}$ The idea that disputes of a particular type are best handled by tribunals set up for the very purpose is nothing new. The Ambalat dispute may be referred to the ITLOS when Indonesia and Malaysia make a declaration accepting its jurisdiction. It also has jurisdiction when any agreement between the two countries so provides. ${ }^{66}$

According to the the UNCLOS, the Ambalat disputes may be referred to arbitration in three different ways. The first way is based on Part XV, Section 1, by which Indonesia and Malaysia may by the agreement select any peaceful means and so can decide to set up an arbitral tribunal along traditional lines. The second

59 Id. art. 284.

60 UNCLOS Annex V.

61 L. Brilmayer \& N. Klein, Land and Sea:Two Sovereignty Regions in Search of a Common Denominator, Faculty Scholarship Series Paper 2523, 706-9 (2001), available at http://digitalcommons.law.yale.edu/fss_papers/2523 (last visited on May 7, 2015).

62 UNCLOS art. 286.

63 For details, see Churchill \& Lowe, supra note 8, at 296.

64 UNCLOS art. 287.

65 For details on the structure and working method of ITLOS, see G. ERriksson, The InTERnational Tribunal FOR THE LAW OF THE SEA (2000). See also Merrils, supra note 16, at 181.

66 Merrils, supra note 16, at 181-2. 
way is based on Part XV, Section 2, by which both parties may declare arbitration as their preferred means of settlement. In that case, arbitration proceedings will be governed by the UNCLOS. The third way is applied as an alternative when there is no common declaration between the two countries under Part XV, Section 2 . Then, the arbitration under the UNCLOS will be deemed to have been accepted by both parties as the relevant obligatory procedures. ${ }^{67}$

Arbitral tribunal under the UNCLOS ${ }^{68}$ are composed of five members, one chosen by each of the conflicting parties and the other three are chosen jointly by the parties, from a panel, to which each State party to the convention may nominate four people. If the disputant can not agree on the three jointly chosen arbitrators, ${ }^{69}$ these are to be appointed by the president of the ITLOS.

Special arbitral tribunal under the UNCLOS can deal with the Ambalat disputes concerning fisheries, environmental protection, scientific research or navigation. ${ }^{70}$ In this case, Indonesia and Malaysia may choose two arbitrators (of whom only one may be its national), respectively, from the appropriate list, and a president, who is to be a national of a third State. ${ }^{71}$ These special tribunal may also act as fact-finding commission. The special tribunal shall apply all the rules of UNCLOS and other rules of international law. The disputant may also agree to request a decision $e x$ aequo et bono. ${ }^{72}$

\section{Conclusion: The Way Forward}

\section{A. Securing Amicable Settlement}

Indonesia and Malaysia have exhaustedall possible and available peaceful way for settlement of its maritime boundary disputes in Ambalat. At the meeting on October 2014, a day after the inauguration of President Joko Widodo of the Republic of Indonesia, the two leaders (President Joko Widodo and Prime Minister Najib Razak) agreed to launch new round of negotiation to settle the Ambalat dispute. ${ }^{73}$

67 Id. at 176.

68 UNCLOS Annex VII.

69 Arbitrators must have some experience in maritime affairs. For details, see Churchill \& Lowe, supra note 8.

70 UNCLOS Annex VIII.

71 Churchill \& Lowe, supra note 8, at 296-7.

72 Id. See UNCLOS Annexes VII art. 4-13 \& VIII (Special Arbitration).

73 Berita Satu, Malaysian Prime Minister Give the First Diplomatic Home Work to Jokowi-Ambalat [PM Malaysia 
So far, the technical committee of the two countries have met nearly 26 times, but no substantive progress have been made. ${ }^{74}$

The author opines ${ }^{75}$ that what technical procedure Indonesia and Malaysia will employ, is not just the matter of resolving the problems. Instead, both have to respect each other by attempting peaceful ways in negotiation. A good understanding in scientific, technical and legal aspects by both sides, will most probably reduce provocative decisions. This must also be understood by laymen in both States, to be able to support the establishment of a fair resolution.

Peaceful settlement may also employ a better approach and actions which accommodate a joint survey, discussion and bilateral agreement. ${ }^{76}$ The approach must be comprehensive and sustainable contributing to mutual benefits for the two neighboring couuntries who may enjoy the energy security and prosperity by exploring and exploiting rich hydrocarbon resources in Ambalat Block.

The Indonesia-Philippines agreement over maritime boundary concluded in Manila on May 23, 2014 can be used as a good lessons of how the intra ASEAN countries manage to settle their maritime boundary peacefully and effectively. ${ }^{77}$ The similar pattern can be invoked to settle the Ambalat case between Indonesia and Malaysia.

The Indonesia-Malaysia relations are too close and precious to be soured over this issue. Both parties thus do their best containing the dispute and settling it amicably for the sake of preserving bilateral ties and regional stability. ${ }^{78}$

\section{B. Possible Solution (including Joint Development and other collaborative development)}

In addition to the above mentioned mechanism, a more pragmatic, practical and innovative options would be addressed.

A possible alternative to the complete delimitation of the Ambalat Block is to

beri PR Diplomasi Pertama Jokowi-Ambalat], Berita SAtu.com, Oct. 21, 2014.

74 Id.

75 Supra note 4 , at 3 .

76 Djoko Harmantyo, A Preliminary Study on the Problem of Indonesia Territorial Boundary, Department of Geography, Faculty of Mathematics and Natural Science, University of Indonesia, Unpublished Document 6, (2006).

77 Arif Havas Oegroseno, Indonesia-Philippines agreement: Lessons for South China Sea Claimants, JAKARTA Post, June 10, 2014, available at http://www.isn.ethz.ch/Digital-Library/Publications/Detail/?ots591=0c54e3b3-1e9cbe1 e-2c24-a6a8c7060233\&lng=en\&id=180702 (last visited on May 7, 2015).

78 For details, see M. Valencia \& N. khalid, The Sulawesi Sea Situation: Stage for Tension or Storm in a Tea Cup? (Unpublished Document), at 5 . 
establish a joint exploration and a joint development zone ("JDZ") by both countries together. The establishment of a JDZ between Indonesia and Malaysia in the Ambalat Block has the potential to ease tension in the region which allows them to utilize the rich seabed and hydrocarbon reserve to improve their energy security, thereby achieving mutual economic benefit. ${ }^{79}$

As a way to consider the possibility and viability of agreeing a JDZ between Indonesia and Malaysia, it is important to consider such conditions as its legal basis, analytical framework, 10 common factors required for joint development, and factors for joint development.

The legal basis for a JDZ can be seen both from general international law as well as customary international law. First, Articles $74(3)^{80}$ and $83(3)^{81}$ of the UNCLOS provide some basic legal justifications for the establishment of a joint development scheme. ${ }^{82}$ Article 123 of the UNCLOS can be another ground. Article 123 stipulates the same. ${ }^{83}$ Second, the legal basis for a JDZ is equally justified by customary international law. The scholars who discuss joint development have become a rule of customary law focus on precedents of joint development in international adjudication and its increased use in bilateral state practice. ${ }^{84}$

Following academic literature and case studies, a modified model of common factors required for joint development has been created. From this analytic framework, ten factors have been organized into primary and secondary or supporting factors and placed into a sequencial structure, which consist of, namely: real claim, good relations and the will to cooperate; political will; absence of islands; knowledge of deposits; unilateral action by a single state; shared culture; need for hydro carbon resources; need for hydrocarbon resources; and previous experience in

79 C. Brown, Sidestepping Maritime Boundary Delimitation: Potential Joint Development of Deep Sea Hydrocarbon in the Ambalat Block, 2 Asian J. Climate Change \& Sustainable Dev. 66-7 (2013). See also Muhammad S. B. H. Yahya, Joint Development: Prospects of Dispute Resolution in Case ND 6 and ND 7, 2 Perkem V Proceedings (2010). Yahya has shown his support for a possibility of establishing joint development in Ambalat Block.

80 UNCLOS art. 74 (3). It provides: "pending agreement as provided for in paragraph 1, the States concerned, in a spirit of understanding and cooperation, shall make every effort to enter into provisional arrangement of a practical natureand, during transitional period, not to hampir or jeopardise or hamper the reaching of the final agreement. Such arrangement shall be without prejudice to the final destination."

81 Id. art. 83 (3). It is almost similar to Article 74 (3). Article 83 (3) just applies to Part VI on the continental shelf issues, while Article 74 (3) applies to Part V on exclusive economic zone.

82 For details, see Brown, supra note 79, at 67-8.

83 It reads: "States bordering an enclosed or semi enclosed sea should cooperate with each other in the exercise of their rights and in performance of their duties." For details, see D. Ong, 1979 and 1990 Malaysia-Thailand Joint Development Agreements: A Model for International Legal Cooperation in Common Off-Shore Petroleum Deposits, 14 Int'L J. Maine \& Coastal L. 782 (1999). See also Rainer lagoni, Interim Measures Pending Maritime Delimitation Agreements, 78 Ам. J. InT'L L. 367 (1984).

84 Zhiguo Gao, The Legal Concept and aspects of joint development in international law, 13 OCEAN Y.B. 109 (1998). 
other joint development schemes; and last but not least, security concerns. ${ }^{85}$

The common factors as applied to Ambalat Block can be elaborated as follows: real claim in the Ambalat Block; absence of islands in the Ambalat Block; knowledge of deposits in the Ambalat Block; good relations and the will to cooperate in Ambalat Block; shared culture in Ambalat Block; need for hydrocarbon resources in the Ambalat Block; political will in the Ambalat Block; previous experience in other joint development schemes; unilateral action by a single state in the Ambalat Block; and security concerns in the Ambalat Block. ${ }^{86}$

Finally, some lessons could be taken from bilateral arrangements between countries related to South China Sea ("SCS"). The following are the examples for finding a good solution to maritime boundary disputes; ${ }^{87}$

1. Track -Two Diplomatic Efforts; 88

2. June 1992 Malaysia and Vietnam MOU to explore and exploit petroleum of defined area of the continental shelf between them;

3. August Agreement Thailand and Vietnam re delimitation of the maritime boundary;

4. The 2002 ASEAN's Declaration on the Code of Parties in the South China Sea ease tensions in Spratley Islands, but is not legally binding;

5. Brunei and Malaysia agreed in september 2008 to resolve their offshore and deep water sea bed disputes, to resume hydrocarbon exploration and to renounce any further territorial claims; and

6. 2008 China and Taiwan agreed jointly to exploit oil and gas resources of the Taiwan Strait and the Diaoyutai/senkaku islands.

Common elements within Joint Development/Transboundary Utilization Agreements are as follows; ${ }^{89}$

1. Spesific designation of a Joint Development Area or Zone (JDA/JDZ);

2. Inclusion of a non-prejudice clause;

3. The obligation to cooperate and negotiate in good faith towards a JDA;

4. Criminal and Civil Jurisdiction within the JDA/JDZ Area;

Brown, supra note 79 , at 71- 7.

6 Id. at 78-85.

87 Supra note 4, at 12-3.

88 Track Two Diplomacy is based on discussions that were informal where participants acted in their personal capacity. For details, see C. Schofield \& I. Story, Energy Security and South East Asia: The Impact of Maritime Boundary and Territorial Disputes, 11 Harv. Asia Q. (2005).

89 D. Ong, Implication of Recent South East Asian State Practice for the International Law on Off-Shore Joint Development, in Beyond Territorial Disputes in the South China Sea ch. 7 (R. Beckman et al. eds., 2013). 
5. Joint institutional framework;

6. Previosly granted concessions;

7. Environmental protection; and

8. Dispute resolution. 
